\title{
Article/Artigo
}

\section{Molecular characterization of the hepatitis $B$ virus in autochthonous and endogenous populations in the Western Brazilian Amazon}

\author{
Caracterização molecular do vírus da hepatite B em população autóctone e população endógena \\ do município de Lábrea, na Amazônia ocidental brasileira
}

\author{
Ádila Liliane Barros Dias ${ }^{1}$, Cintia Mara da Costa Oliveira ${ }^{2}$, Márcia da Costa Castilho ${ }^{1,2}$, Maria do Socorro \\ Pontes da Silva ${ }^{3}$ and Wornei Silva Miranda Braga ${ }^{2}$
}

\begin{abstract}
Introduction: Hepatitis B virus (HBV) infection is a serious public health issue worldwide. Hepatitis $B$ virus is classified into eight genotypes, varying from $A$ to $\mathrm{H}$, with distinct geographical distributions. In Brazil, the most frequent genotypes are A, D, and F. Methods: This study aimed to characterize the HBV genotypes in cases of hepatitis B virus and hepatitis D virus (HDV) co-infections in an endemic area in the Western Brazilian Amazon. We analyzed 86 serum samples reactive for $\mathrm{HBs} A g$ from indigenous and non-indigenous populations obtained from previous serological surveys. Results: Of the 86 reactive serum samples, 39 were found to be HBV-DNA-positive by semi-nested PCR. The genotypes were established by sequencing the amplified $S$ gene region. We obtained 20 sequences classified into three genotypes: A, D, and F. Genotype A was the most frequent (60\%), followed by D (35\%) and F (5\%). Conclusions: The distribution of the HBV genotypes reflected the pattern of historical occupation of the region.
\end{abstract}

Keywords: Hepatitis B virus. Genotypes. Epidemiology. Amazon. Brazil.

\begin{abstract}
RESUMO
Introdução: A infecção pelo vírus da hepatite B (VHB) é um importante problema de saúde pública no mundo. O VHB é classificado em oito genótipos diferentes, A-H, com distinta distribuição geográfica. No Brasil, os genótipos mais frequentes são o A, D e F. Métodos: Objetivo deste estudo foi caracterizar os genótipos do VHB, em região endêmica de infecção pelos vírus da hepatite B e hepatite D (VHD), na Amazônia Ocidental Brasileira. Foram analisadas 86 amostras sororreativas para o HBsAg de indivíduos indígenas e não-indígenas, obtidas de inquéritos sorológicos realizados no município de Lábrea, Estado do Amazonas. Resultados: Das 86 amostras sororreativas, 39 foram VHB-DNA positivas pela semi-nested PCR. Os genótipos foram estabelecidos pelo sequenciamento da região do gene $S$ amplificado. Foram obtidas 20 sequências, classificadas em três genótipos A, D e F; sendo o genótipo A o mais frequente (60\%), seguido do D (35\%) e F (5\%). Conclusões: O perfil de distribuição dos genótipos encontrados do VHB reflete o padrão de ocupação histórica da região.
\end{abstract}

Palavras-chaves: Vírus da hepatite B. Genótipos. Epidemiologia. Amazônia. Brasil.

\footnotetext{
1. Programa de Pós-Gradação em Medicina Tropical, Universidade do Estado do Amazonas, Manaus, AM. 2. Gerência de Virologia, Fundação de Medicina Tropical Doutor Heitor Vieira Dourado, Manaus, AM. 3. Secretaria de Saúde, Prefeitura Municipal de Lábrea, Lábrea, AM.

Address to: Dr. Wornei Silva Miranda Braga. Gerência de Virologia/FMT-HVD. Av. Pedro Teixeira 25, 69040-000 Manaus, AM, Brasil.

Phone/Fax: 5592 3238-3762

e-mail: wornei.braga@hotmail.com

Received in 13/04/2011

Accepted in 20/06/2011
}

\section{INTRODUCTION}

Hepatitis B represents one of the most prevalent viral infections in the world. There are at least 2 billion people with serological evidence of hepatitis $B$ virus (HBV) infection; 350 million of these are patients with chronic disease, with higher risk of death from cirrhosis and hepatocellular carcinoma ${ }^{1}$.

Hepatitis B virus belongs to the genus Orthohepadnavirus of the Hepadnaviridae family. It is composed of a circular double-stranded DNA particle where the negative strand is complete and the positive one is incomplete at the 5 ' end. It is an enveloped virus, $42 \mathrm{~nm}$ in diameter, and with 3,200 nucleotides ${ }^{2}$. It can be classified phenotypically into four subtypes, which in turn may be further classified according to the antigenic determinant of the surface antigen (HBsAg): adw, ayw, adr, and ayr $^{2-3}$. HBV can also be classified by genotype into eight strains, ranging from $\mathrm{A}$ to $\mathrm{H}^{4}$. Their structural and functional differences are associated with clinical severity, treatment failure, and possible interference with vaccine response. These genotypes can vary up to $8 \%$ within its genome ${ }^{5}$.

The different genotypes have a varied distribution; genotype A has a universal distribution, being the predominant genotype in Europe, North America, Africa, and India. Genotypes B and C are predominant in Eastern and Southeast Asia and Australia. Genotype D is mainly found in the Middle East and the Mediterranean. Genotype E seems to be predominant in West Africa, whereas genotype $G$ is distributed throughout the United States, Mexico, and France. Genotype F is mainly found in Central and South America and Alaska. Finally, genotype $\mathrm{H}$ is unique to Central America and the United States ${ }^{5-7}$.

The Brazilian Amazon region is characterized as one of the regions of the world with a high occurrence of HBV-associated disease and its sequelae ${ }^{8}$. The State of Amazonas, the Brazilian Amazon, the Juruá, the Solimões, and the Purus 
river basins are considered areas of high endemicity of HBV and Delta (HDV) infections ${ }^{9-10}$. Among the indigenous population of the Western Amazon, serum epidemiological studies reported prevalence rates of chronic carriers above $20 \%$.

In the Brazilian Amazon, genotype A has been shown to be the most commonly found genotype, followed by genotypes $\mathrm{D}$ and $\mathrm{F}^{12}$. However, genotype $\mathrm{F}$ is generally the most prevalent genotype in isolated indigenous communities ${ }^{13}$.

This study aimed to perform phylogenetic analyses to characterize the HBV genotype isolates from HBsAg-reactive subjects and to identify these in a population basis prevalence study done in an endemic area of HBV infection in the Western Brazilian Amazon. Our results may reveal differences concerning HBV distribution. The analyses were performed on the nucleotide sequences of the $S$ regions of surface genes.

\section{METHODS}

\section{Specimens}

We conducted a molecular epidemiological study of genotypic characterization of $\mathrm{HBV}$ in individuals positive for the HBsAg antigen in urban, rural, and indigenous communities from the county of Lábrea in the province of the Amazonas (Figure 1).

The selected samples were collected during the course of crosssectional serological surveys of $\mathrm{HBV}$ infection, including the general asymptomatic population from urban and rural villages of Lábrea County, from February 2006 to July 2008.

A total of 1,510 samples were analyzed by enzyme-linked immunosorbent assay (ELISA) for HBV (HBsAg) and HDV markers (anti-HD IgG), using a commercial kit (DiaSorin, S.p.A.,

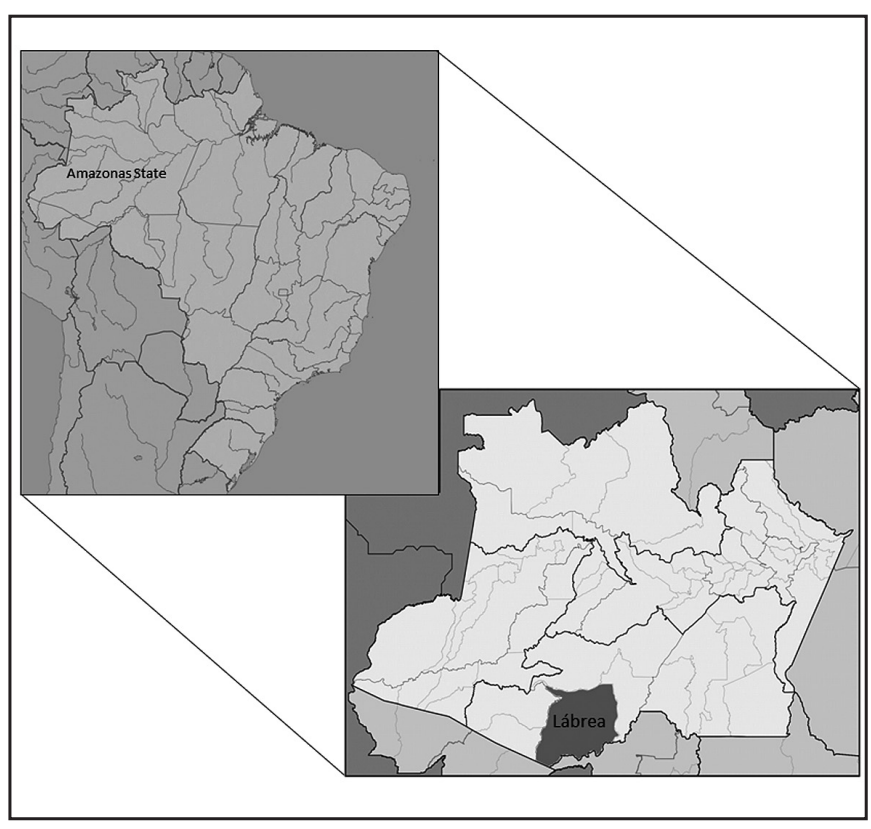

FIGURE 1 - Map of the study area.
Saluggia, Italy). The test procedures followed the manufacturer's recommendations and were performed automatically at the laboratory facilities of the Virology Unit of Tropical Medicine Foundation Doutor Heitor Vieira Dourado (FMT-HVD).

\section{DNA extraction}

Viral DNA was extracted from the serum samples using the Qiamp DNA Blood Mini Kit (Qiagen Sciences, Maryland, USA), according to the procedures recommended by the manufacturer. A single change was made in the protocol of increasing the time of digestion with proteinase $\mathrm{K}$ and the Assay Lyses buffer (AL) to $4 \mathrm{~h}$.

\section{Polymerase chain reaction}

The $S$ region of the surface gene was amplified by semi-nested polymerase chain reaction (PCR). In the first reaction, we used the primers 783 (5'-CTC ACG ATG CTG TAC AGA CTT-3'), nt 783762, and 2821 (5'-GGG TCA CCA TAT TCT TGG GAA CA-3'), nt 2821-2150 [X51970.1 GenBank access]. In the second reaction, the primers 783 and $\mathrm{P}^{14}$ were used, resulting in products of $1,200 \mathrm{bp}$ and $680 \mathrm{bp}$, respectively.

For the amplification of DNA, $5.0 \mu \mathrm{L}$ from the sample was used for the first reaction, and $1.0 \mu \mathrm{L}$ of the PCR product was used for the second reaction to a mixture containing: $5.0 \mu \mathrm{L} 10 \times \mathrm{PCR}$ buffer, $2.0 \mu \mathrm{L}$ of dNTP mix $(10 \mathrm{mM}), 2.0 \mu \mathrm{L} \mathrm{MgCl}_{2}(50 \mathrm{mM}), 2.0 \mu \mathrm{L}$ of each primer, and $0.4 \mu \mathrm{L}$ of platinum Taq DNA polymerase $(5 \mathrm{U} / \mu \mathrm{L})$ (Invitrogen, San Diego, CA, USA), resulting in a final volume of $50 \mu \mathrm{L}$. The cycle conditions used initially were $94^{\circ} \mathrm{C}$ for $5 \mathrm{~min}$ for denaturing, followed by 35 cycles of $94^{\circ} \mathrm{C}$ for $30 \mathrm{~s}, 52.6^{\circ} \mathrm{C}$ for $2 \mathrm{~min}, 72^{\circ} \mathrm{C}$ for $30 \mathrm{~s}$, and a final extension of $72^{\circ} \mathrm{C}$ for $7 \mathrm{~min}$ in a Mastercycler Gradient thermocycler (Eppendorf, Hamburg, Germany).

\section{Sequencing}

The samples were purified with a Wizard SV Gel kit and a PCR Clean-Up System (Promega, Madison WI, USA), sequenced with forward and reverse primers using a Big Dye Terminator 3.1 Cycle Sequencing Kit (Applied Biosystems, Foster City, CA, USA), according to the manufacturer's instructions. The reactions were performed in an automatic Sequencer ABI PRISM 3130 XL Genetic Analyzer (Applied Biosystems).

\section{Sequence analysis}

To confirm the virus type, the sequences obtained were analyzed using the GenBank BLAST tool. Subsequently, the sequences were edited and aligned using the BioEdit Sequence Alignment Edit version 7.0.9.0 ${ }^{15}$. Thirty sequences obtained from GenBank, corresponding to the eight genotypes of $\mathrm{HBV}$, were used for the alignment.

\section{Genotype identification}

We performed a phylogenetic analysis comparing the different genotypes of HBV obtained from the eight GenBank sequences (X75666, X75662, X75657, X75667, AF160501, AY090460, $\mathrm{X} 69798, \mathrm{D} 00329)$. The phylogenetic analysis and molecular evolution were performed using the Molecular Evolutionary Genetics Analysis (MEGA) Program version 4.0.2. ${ }^{16}$. The Neighbor-Joining (NJ) model was used for the construction of phylogenetic trees. The confidence level was obtained using the nonparametric bootstrap method based on 1,000 replicates. The genotypes were classified by similarity analysis of sequences obtained in the study and sequences 
corresponding to genotypes A to $\mathrm{H}$ obtained from GenBank. The HBV of non-human primates (accession number GenBank AF046996) was used as the outgroup.

\section{Ethical considerations}

This study was reviewed and approved by the Research Ethical Commission of FMT-HVD, Manaus, Amazonas, Brazil (N: 2957/2003/FMT; No.: 1775/2006/FMT).

\section{RESULTS}

Of the 1,510 samples, 86 were HBsAg-reactive. Thirty-one belong to indigenous individuals and 55 to non-indigenous individuals. Of the $86 \mathrm{HBsAg}$-reactive, 56 (65.1\%) were anti-HD IgG-reactive. HBV DNA by semi-nested PCR was positive in $45.3 \%$ (39/86). This percentage was $37.5 \%$ (21/56) for those co-infected with HDV.

Twenty-two samples were submitted to sequencing of the $S$ region of the surface gene and were compared with the eight sequences obtained from GenBank.

The most common genotype was A, found in 60\% (12/20), followed by genotype D, with $35 \%$ (7/20). Genotype F was only found in one sample, representing 5\% (1/20) (Figure 2).

Among the samples from indigenous people, 44.4\% (4/9) had genotype A, and $55.6 \%$ (5/9) had genotype D. Of the non-indigenous samples, genotype A was prevalent with $72.7 \%$ incidence (8/11), followed by genotype $\mathrm{D}$ with $18.2 \%(2 / 11)$ and genotype $\mathrm{F}$ with $9.1 \%(1 / 11)$.

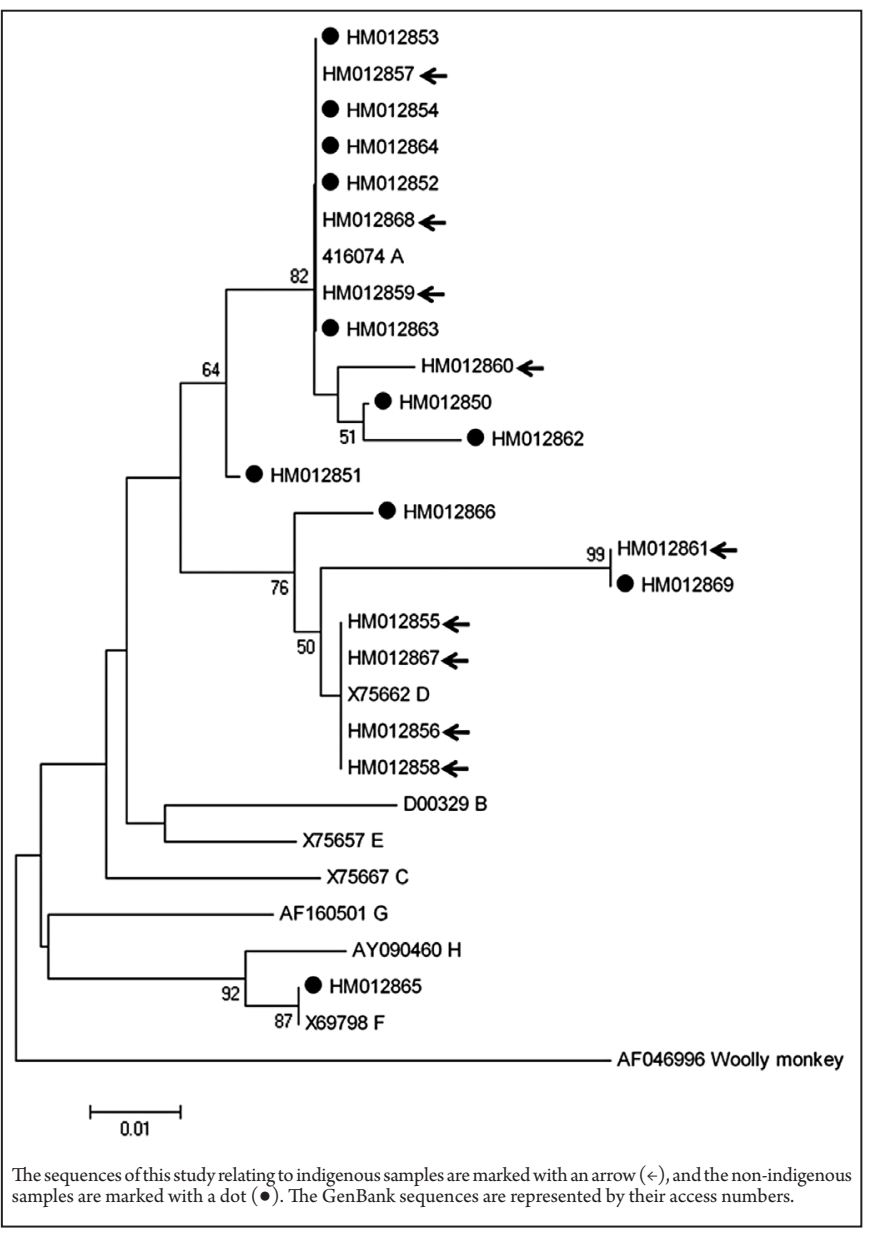

FIGURE 2 - Neighbor-Joining phylogenetic tree from hepatitis B virus DNA $(S$ gene) representing the genotypes found.

\section{DISCUSSION}

The results of this study contribute to the information regarding the distribution of HBV genotypes in the Western Brazilian Amazon, as molecular epidemiology studies of $\mathrm{HBV}$ in that region are still scarce. As the geographical distribution of HBV genotypes is very diverse ${ }^{5}$, the molecular characterization of HBV genotypes in a given region can reveal aspects of the origin of the virus in populations of that region.

The samples evaluated in this study showed a predominance of genotypes $\mathrm{A}$ and $\mathrm{D}$, whereas genotype $\mathrm{F}$ was only found in one sample. Studies on the distribution of HBV genotypes in Brazil and the Amazon also show that in the northern region, genotype $\mathrm{A}$ is the most common, followed by genotype $\mathrm{D}$ and genotype $\mathrm{F}^{12,17-19}$. However, other studies performed in the Brazilian Amazon revealed that genotype $\mathrm{F}$ is more prevalent ${ }^{20-22}$.

We believe that this difference could be associated with the type of samples evaluated; while our samples were from a populationbased prevalence study, including asymptomatic individuals, the majority of the studies' published samples were usually derived from patients with established chronic disease or from patients with fulminant hepatitis ${ }^{21,23}$.

In the past decade, genotype $\mathrm{F}$ was identified at a higher frequency in Amerindians ${ }^{13}$. This genotype is frequent in isolated tribes in the Amazon with no contact with non-indigenous people ${ }^{24}$. The same study showed that contact with non-indigenous people favored the introduction of genotypes $\mathrm{A}$ and $\mathrm{D}$ into these populations.

When analyzing samples previously characterized by a monoclonal antibody technique compared with primers for genotype $\mathrm{F}$, we identified genotype $\mathrm{A}$ as the most frequent, followed by $\mathrm{D}$ and $F$, which suggested that there was an over-estimation of genotype $F$ in other studies because they used monoclonal antibodies to identify the serotypes ${ }^{18}$.

The study region was first reached in the late nineteenth century during a collection of forest products and then again in the middle of the twentieth century during the rubber boom, with a great migration of people from the northeast region of Brazil into this region ${ }^{25-28}$.

It has been reported that about $50 \%$ of HBV circulating in the country is genotype A, from an African subtype, possibly related to the introduction of Africans in Brazil by the slave trade ${ }^{29}$. Besides the influence of African origin, the influence of European colonization and the presence of Lebanese peddlers in the Amazon region during the period of rubber exploitation ${ }^{30}$ may explain the strong presence of genotypes $\mathrm{A}$ and $\mathrm{D}$ that were found in our samples.

We found only a positivity of $45.3 \%$ (39/86) of viral DNA in our sample, whereas other studies showed higher positivity rates, such as $76 \%{ }^{19,31}$. Our results may be influenced by the large number of individuals co-infected with HDV at $65.1 \%$ (56/86), which spontaneously suppresses $\mathrm{HBV}^{32-33}$, as well as problems in handling the samples during field work in precarious places such as the rural Amazon.

This study defines the HBV genotype profile in the region and suggests that HBV distribution is possibly heterogeneous in the Amazon. The detected HBV genetic profile is, in fact, associated with the historic human occupation of the study region. 


\section{ACKNOWLEDGMENTS}

The authors thank FUNASA (DSEI Meddle Purus), Ministry Health of Brazil, for supporting this research with indigenous populations and communities in both the urban and rural municipalities of Lábrea.

\section{CONFLICT OF INTEREST}

The authors declare that there is no conflict of interest.

\section{FINANCIAL SUPPORT}

This work was financially supported by the Fundação de Amparo à Pesquisa do Amazonas (FAPEAM), Conselho Nacional de Desenvolvimento Científico e Tecnológico (CNPq) e Coordenação de Aperfeiçoamento de Pessoal de Nível Superior (CAPES).

\section{REFERENCES}

1. Sharma SK, Saini N, Chwla Y. Hepatitis B virus: inactive carriers. Virol J 2005; 2:82-86

2. Okamoto H, Tsuda F, Sakugawa H, Sastroewignjo RI, Imai M, Miyakawa Y, et al. Typing hepatitis B virus by homology in nucleotide sequence: comparison of surface antigen subtypes. J Gen Virol 1988; 69: 2575-2583.

3. Bancroft WH, Mundon FK, Russell PK. Detection of additional antigenic determinants of hepatitis B antigen. J Immunol 1972; 109:842-848.

4. Kidd-Ljunggren K. Miyakawa Y, Kidd AH. Genetic variability in hepatitis B viruses. J Gen Virol 2002; 83:1267-1280.

5. Norder H, Couroucé AM, Coursaget P, Echevarri JM, Lee SD, Mushahwar IK, et al. Genetic Diversity of Hepatitis B virus strains derived worldwide: Genotypes, subgenotypes, and HBsAg subtypes. Intervirology 2004; 47: 289-309.

6. Campos RH, Mbayed VA, Pineiro YLFG. Molecular epidemiology of hepatitis B virus in Latin America. J Clin Virol 2005; 34:8-13.

7. Weber B. Diagnostic impact of the genetic variability of the hepatitis B virus surface antigen gene. J Med Virol 2006; 78:59-65.

8. Braga WSM, Brasil LM, Souza RAB, Castilho MC, Fonseca JC. Ocorrência da infecção pelo vírus da hepatite $\mathrm{B}$ (VHB) e delta (VHD) em sete grupos indígenas do Estado do Amazonas. Rev Soc Bras Med Trop 2001; 34:349-355.

9. Bensabath G, Leão RNQ. Epidemiologia na Amazônia brasileira In: Focaccia R, editor. Tratado de Hepatites Virais. São Paulo: Editora Atheneu; 2003. p. 1-26.

10. Braga WSM, Silva EB, Souza RAB, Tosta CE. Soroprevalência da infecção pelo vírus da hepatite $\mathrm{B}$ e pelo plasmódio em Lábrea, Amazonas: estimativa da ocorrência de prováveis coinfecções. Rev Soc Bras Med Trop 2005; 38:218-223.

11. Braga WSM. Infecção pelos vírus das hepatites B e D entre grupos indígenas da Amazônia Brasileira: aspectos epidemiológicos. Rev Soc Bras Med Trop 2004; 37:9-13

12. Mello FCA, Souto FJD, Nabuco LC, Villela-Nogueira CA, Coelho HS, Franz HC, et al. Hepatitis B virus genotypes circulating in Brazil: molecular characterization of genotype F isolates. BMC Microbiol 2007; 7:103.

13. Blitz L, Pujol FH, Swenson PD, Porto L, Atencio R, Araujo M, et al. Antigenic diversity of hepatitis B virus strains of genotype $\mathrm{F}$ in Amerindians and other population groups from Venezuela. J Clin Microbiol 1998; 36:648-651.

14. Oliveira CM, Farias IP, Fonseca JCF, Brasil LM, Souza R, Astolfi-Filho A. Phylogeny and molecular genetic parameters of different stages of hepatitis $\mathrm{B}$ vírus infection in patients from the Brazilian Amazon. Arch Virol 2008; 12:27-37.

15. Hall TA. BioEdit: a user-friendly biological sequence alignment editor and analysis program for Windows 95/98/NT. Nucl Acids Symp Ser 1999; 41: 95-98.

16. Tamura K, Dudley J, Nei M, Kumar S. MEGA4: Molecular Evolutionary Genetics Analysis (MEGA) software version 4.0.2. Mol Biol Evol 2007; 24:1596-1599.
17. Ferreira RC, Teles AS, Dias MA, Tavares VR, Silva AS, Gomes AS, et al. Hepatitis $B$ virus infection profile in haemodialysis patients in Central Brazil: prevalence, risk factors, and genotypes. Mem Inst Oswaldo Cruz 2006; 101:689-692.

18. Moraes MTB, Niel C, Gomes SA. A polymerase chain reaction-based assay to identify genotype F of hepatitis B virus. Braz J Med Biol Res 1999; 32:45-49.

19. Carrilho FJ, Moraes CR, Pinho JRR, Mello IMVGC, Bertolini DA, Lemos MF, et al. Hepatitis B vírus infection in hemodialysis centres from Santa Catarina State, Southern Brazil. Predictive risk factors for infection and molecular epidemiology. BMC Public Health 2004; 4:13.

20. Viana S, Parana R, Moreira RC, Compri AP, Macedo V. High prevalence of hepatitis B virus and hepatitis D virus in the western Brazilian Amazon. Am J Trop Med Hyg 2005; 73:808-814.

21. Victoria FS, Oliveira CMC, Victoria MB, Victoria CB, Ferreira LCL. Characterization of $\mathrm{HBeAg-negative} \mathrm{chronic} \mathrm{hepatitis} \mathrm{B} \mathrm{in} \mathrm{western} \mathrm{Brazilian}$ Amazonia. Braz J Infect Dis 2008; 12:27-37.

22. Conde SRSS, Móia LJP, Barbosa MSB, Amaral ISA, Miranda ECBM, Soares MCP, et al. Prevalência de genótipos e de mutantes pré-core A-1896 do vírus da hepatite $\mathrm{B}$ e suas implicações na hepatite crônica, em uma população da Amazônia oriental. Rev Soc Bras Med Trop 2004; 37:33-39.

23. Paraná R, Vitvitski L, Pereira JE. Hepatotropic Viruses in the Brazilian Amazon A Health Threat. Braz J Infect Dis 2008; 12: 253-256.

24. Bertolini DA, Moreira RC, Soares MCP, Bensabath G, Lemos MF, Mello IMVGC, et al. Genotyping of hepatitis B virus in indigenous populations from Amazon region, Brazil [abstract]. Virus: Reviews and Research 2000; 5:101.

25. Ribeiro CL. Os Estados Brasileiros [Internet] 2009 - [cited 2011 Jan 5]; Available from: http://www.carlosribeiro.caestamosnos.org/HistoriaBrasil/Estado_Acre. html.

26. Governo do Amazonas. Biblioteca virtual-BV [Internet]. Governo do Amazonas 2009 - [cited 2011 Jan 5]; Available from: http//www.bv.am.gov.br/portal/ conteúdo /municípios/labrea.php.

27. Schröder P. Povos Indígenas no Brasil [Internet]. 2002 - [cited 2011 Jan 5]; Available from: http://pib.socioambiental.org/pt/povo/paumari/print.

28. Schiel J. Povos Indígenas no Brasil [Internet]. 2005 - [cited 2011 Jan 5]; Available from: http://pib.socioambiental.org/pt/povo/apurina/print.

29. Teles AS, Martins RMB, Vanderborght B, Stuyver L, Gaspar AMC, Yoshida CFT. Hepatitis B virus: Genotypes and subtypes in Brazilian hemodialysis patients. Artificial Organs 1999; 23:1074-1078.

30. Bastani J, Campos MA. Turco pobre, sírio remediado, libanês rico: a trajetória do imigrante libanês no Espírito Santo. Vitória: Instituto Jones Santos; 1987.

31. Chu CJ, Keeffe EB, Han SH, Perrillo RP, Min AD, Pico CS, et al. Prevalence of $\mathrm{HBV}$ precore/core promoter variants in the United States. Hepatology 2003; 38:619-628.

32. Kiesslich D, Crispim, MA, Santo C, Ferreira FL, Fraiji NA, Komoninakis SV, et al Infuence of hepatitis B virus (HBV) genotype on the clinical course of diseases in patients coinfected with HBV and hepatitis Delta virus. The J Infect Dis 2009; 199:1608-1611.

33. Rizzetto M. Hepatitis D: thirty years after. J Hepatol 2009; 50:1043-1050. 